\title{
Red/Gray Tiger Top Serum Separator Tube
}

National Cancer Institute

\section{Source}

National Cancer Institute. Red/Gray Tiger Top Serum Separator Tube. NCI Thesaurus.

Code C129963.

A blood collection tube with a coagulant and a gel, used for serum determinations in chemistry. 